\title{
Going Glocal in a Pandemic: Can Japan Offer Lessons for Others?
}

Masaaki Takemura

Meiji University

Follow this and additional works at: https://digitalcommons.uri.edu/mgdr

Part of the Anthropology Commons, Economics Commons, Japanese Studies Commons, Marketing Commons, Other Business Commons, and the Sociology Commons

\section{Recommended Citation}

Takemura, Masaaki (2020) "Going Glocal in a Pandemic: Can Japan Offer Lessons for Others?," Markets, Globalization \& Development Review. Vol. 5: No. 4, Article 5.

DOI: 10.23860/MGDR-2020-05-04-05

Available at: https://digitalcommons.uri.edu/mgdr/vol5/iss4/5

This Dialogue is brought to you for free and open access by DigitalCommons@URI. It has been accepted for inclusion in Markets, Globalization \& Development Review by an authorized editor of DigitalCommons@URI. For more information, please contact digitalcommons-group@uri.edu. 
Going Glocal in a Pandemic: Can Japan Offer Lessons for Others?

\section{Markets, Globalization \& Development Review}
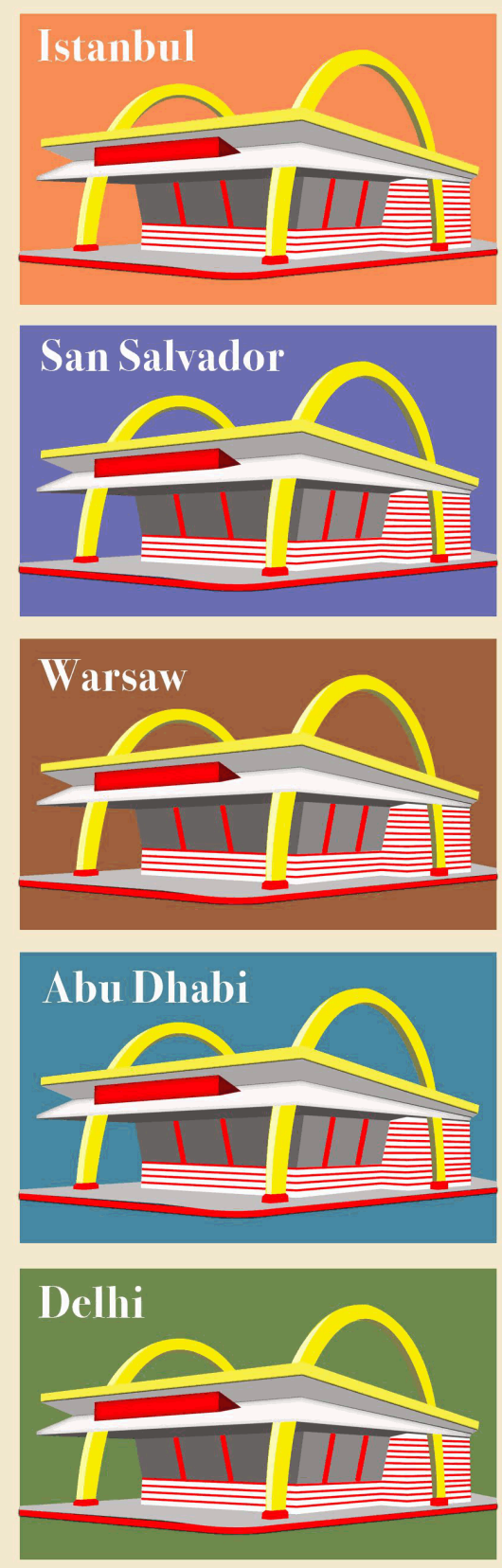
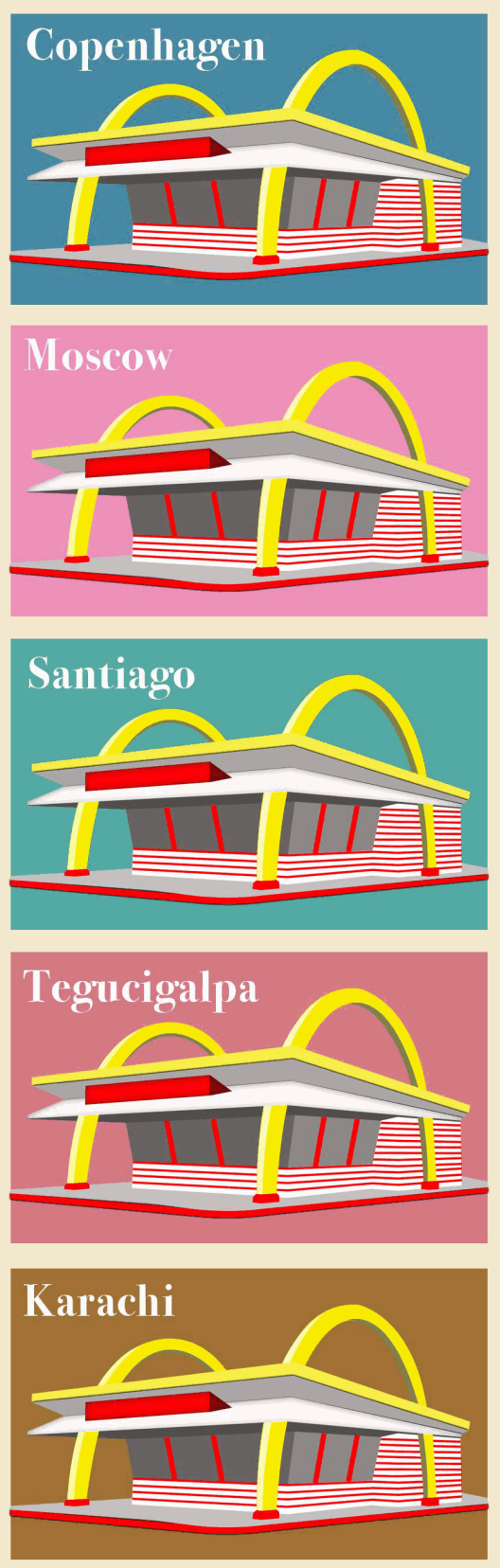
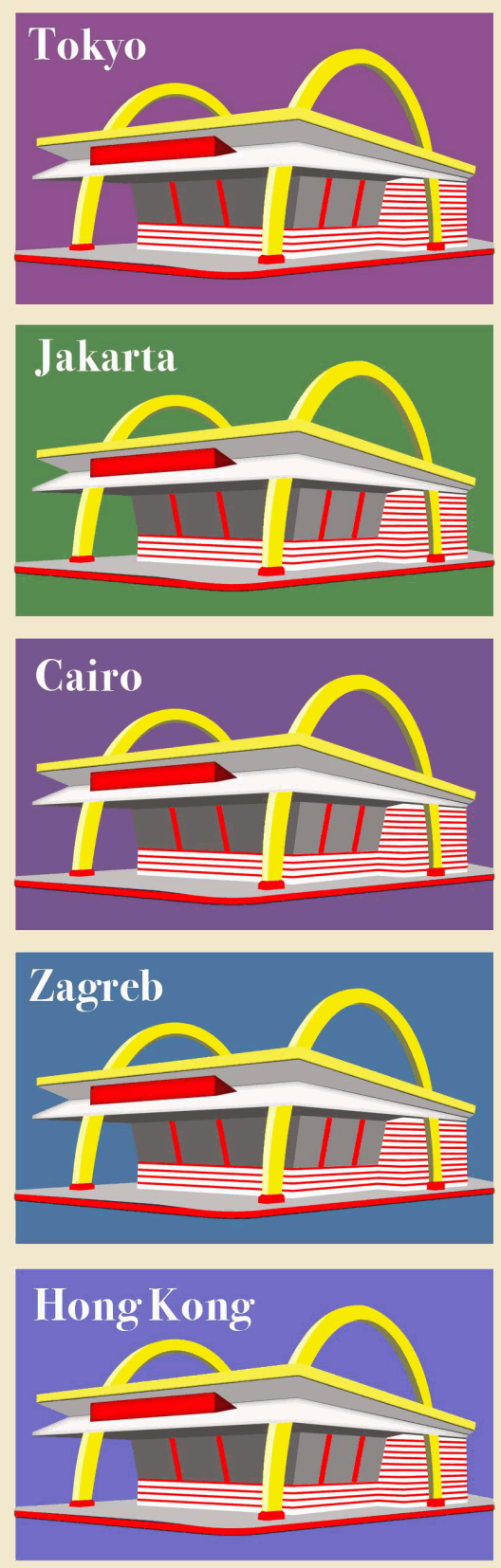

This dialogue is available in Markets, Globalization \& Development Review: https://digitalcommons.uri.edu/mgdr/ 


\section{Going Glocal in a Pandemic: Can Japan Offer Lessons for Others?}

\section{Searching for Lessons from Japan Glocal}

The COVID-19 pandemic attacked the worldwide economy. While the long-term effects of the pandemic are still unpredictable, leaders in most countries have begun to look for ways of rebuilding their damaged economies. One possible way to revive the damaged economies is not only to mitigate lockdowns and allow retail and restaurant operations domestically, but also to reopen the borders and restart international economic activities. Several EU countries began to accept travelers from the $27 \mathrm{EU}$ countries and other Schengen countries. Of course, as new waves of the pandemic emerged in various countries, the policies of keeping borders open or closed kept changing, often abruptly.

In this situation, the leaders try to learn which countries have managed the pandemic well in order to contain it. Till the end of June 2020 (the first wave of the pandemic), Japan was one of the countries which managed well in terms of minimizing the impacts of this pandemic (Harding 2020; Saito 2020). Even after the third wave had come in November and December 2020, The Economist (2021) focused on global overestimation or underestimation of pandemic deaths. According to this report, the death count in most countries was extremely underestimated. The Economist estimated that actual deaths in many countries were twice to four times the reported numbers. The worst country - according to this report - was Russia. The report applauded Japan's achievement, where it seems deaths were over-reported by 30,000 ; i.e., actual deaths were fewer than what was reported.

Japan coped with this pandemic with extremely low number of PCR (polymerase chain reaction) tests and quite lax declarations and enforcements of emergency. Furthermore, the emergency statement issued by the Prime Minister Abe on April 7, 2020 was not accompanied by legal punishments and penalties. It was nothing more than a "please do, please don't" plea for restraints about going out and suggestions for closing shops and restaurants. While enforced lockdown was not implemented in Japan, most of the Japanese heeded the plea and followed the suggested guidelines. The Japanese people spontaneously stayed home from April 8 to May 7, 2020.

The purpose of this Dialogue contribution is to search for lessons from the Japanese countermeasures against the COVID-19 pandemic. This contribution approaches this issue from a social point of view. Specifically, it focuses on social understanding process of an uncertainty event - in this case the COVID-19 pandemic - by the Japanese. The exploration of this understanding process can reveal 
what the "Japanese Glocal" characteristics are. The discussion starts with the typical Japanese way of 'being convinced'.

What follows deals with three topics. The first is a summary of the typical Japanese attitude toward change of conditions. From this discussion, we learn that we Japanese are overwhelmingly confident in our methods when the conditions are stable, but - once conditions change - we quickly lose our confidence. This rapid, almost radical, shift of assertions is a peculiarly Japanese way of thinking and reflection. The first example in the discussion that follows is about the high praise of Japanese management around 1970s, and the rapid disappearance of such praise. The second example - of the Japanese attitudes toward changing conditions - is based on the debate on globalization that took place in Japan in the 1980s. To the Japanese, globalization initially represented absolute uncertainty. In the beginning, the Japanese criticized the emerging globalization conditions and insisted on the adjustment to these conditions. Next came the counterarguments. Then - this is important - the Japanese quit the discussions and were watching what happens next. This is the typical process for the Japanese to understand the uncertainty of unfolding events.

The third part of this contribution is the discussion and evaluation of the Japanese attitude and countermeasures against COVID-19 in 2020. From this discussion, we can glean the "flip-flop" attitude evident in Japan. This attitude can be characterized as rapid change of one's opinions, as if swinging wildly from right to left. This attitude stems from the 'unlearning' habit of Japanese, that we call the "Japanese Glocal". Finally, this paper concludes that there remain huge difficulties in learning from Japan's 'success' against COVID-19; and uncertainties and challenges continue.

\section{Discussions on COVID-19, Deja Vu}

This section discusses the general Japanese attitude toward changing conditions. It illustrates a parallel structure of Japanese attitudes to changing conditions, which were experienced in the 1970s, and the present times. The high-praise of Japanese management in that period resembles the praise for the COVID-19 countermeasures of Japan.

As discussed above, compared to EU countries and United States, Japan - at least in the first half of 2020 - was recognized as one of the countries that successfully managed the COVID-19 pandemic. Therefore, some countries began to explore the Japanese ways. This is because Japan seems to have responded to COVID-19 better than the EU and the United States without strict and severe lockdowns, in spite of Japan's statistics of COVID-19 pandemic - in terms of the cases and deaths per million - being higher than other Asian countries that had very strict controls. 
Many varieties of hypotheses about Japan's relative pandemic success without strict lockdowns - from the BCG (Bacillus Calmette-Guérin vaccine, the anti-tuberculosis vaccine, given to babies) thesis to notions of the Japanese sanitary habits - have been advanced. The BCG (tuberculosis or TB preventive vaccination) angle argues that countries with TB cases, and the use of the BCG vaccination at infancy, have fewer number of COVID-19 deaths (Shivendu et al. 2020). With regard to the local habits hypothesis, Mr. Aso of the Ministry of Finance - well-known for his frequent gaffes declared that the salutary results regarding the pandemic can be explained by the 'highly civilized level' of Japanese people. His features of the highly civilized level included spontaneous restraints on going out, always wearing a mask, washing hands well, gargling, and removing shoes when entering houses.

When examining the June 2020 situation (of claimed success against the pandemic), we should recall the kind of discussions the Japanese had in March 2020, early days of the pandemic. Those discussions strongly criticized the delayed response by the government, with warnings of medical system collapse, and praise for the strict and rigorous lockdowns in foreign countries. In April, Dr. Shibuya, Professor at Kings College in London, warned that Japan's countermeasures to COVID-19 were out of step compared to the global standards: he argued for strict lockdowns, much more intensive PCR testing, and quick quarantine policies (Shibuya 2020). In general, countermeasures against COVID-19 in Japan were worse than those in the US, UK, France, and Germany.

This "flip-flop" attitude is a peculiar characteristic of the Japanese. Such patterns of attitudes can be seen in many cases. The most famous one was the attitude toward the Emperor when the World War II was over. Before January 1, 1946, the Emperor was an avatar of the Supreme Deity, divinity incarnate in human form. When Japanese soldiers died in war, these deaths were praised as occurring for the divine Emperor's sake. On January 1, 1946, the Supreme Commander of the Allied Powers asked the Showa Emperor, Hirohito, to proclaim the Humanity Declaration. The Japanese quickly fell in line and recognized the Emperor as a human.

A similar structure of such attitude flip-flops can be seen in the 1970s - when there was high praise for Japanese management. In those days, the Japanese had big boosts in confidence because observers from the United States of America, the victorious country in World War II, praised Japanese management, with the book Japan as Number One becoming an icon (Vogel 1979). Before this work, typical Japanese success stories were characterized by specific management methods: permanent employment, seniority-wage system, and enterprise-specific unions (Abegglen 1958). Unlike the prevailing 
discussions about Japanese success, Vogel (1979) attributed and analyzed Japan's managerial success from a cultural point of view. He found that the Japanese showed strong will and habits for learning and reading. Japanese reading habits were twice as strong and prevalent as those of Americans, evidenced in the large number of bookstores and high circulation of newspapers in Japan. Going further, Vogel recommended that Americans can learn from Japanese diligence. Some of advocates even went so far as to say that - having climbed to the Number One spot - in Japan, nothing remained to be learned from America (Morita, Reingold and Shimomura 1986).

Of course, we cannot continue to trace back the discussions of the contemporary times to the 1970s because the vaunted Japanese management system was already regarded as having many elements that retarded Japan's ability to adjust to global standards in the 1980s and beyond. Therefore, we need to turn next to discussions about Japan's adjustments to globalization.

\section{Discussions on Globalization in Japan}

Early in the 1980s, Japan encountered big uncertainty of unfolding events, in terms of rapid globalization. Not only in business sectors, but also in public sectors, including education, the Japanese were afraid of globalization because it would destroy their everyday lives.

During such times and phases, the Japanese often make arguments that are often polarized to the extreme. In Japan, one side of the argument regarding globalization was this process as borderless, and the other and polar side was about globalization with 'borderfullness'. The border implies many kinds of obstacles, such as country's own laws, tariffs, trade customs, and non-tariff barriers to trade; hence borderless economy refers to one with no barriers. In an extreme case, borderless means that one global regulation covers world's economic transactions. In contrast, borderfull(ness) implies that several obstacles remain and interfere with such ideal and smooth, unfettered economic transactions.

One side in this debate warned that Japanese management was not diversified, the Japanese decision processes were too slow, and Japanese regulations put barriers for foreign investors to enter Japanese markets. Therefore, those Japan-specific customs should be updated to adjust to the global era (Ohmae 1990).

Structural Impediments Initiatives (SII) was the typical example of this type of discussion. SIl began to reduce international trade deficit of USA in 1989. United States Department of the Treasury recognized that the closed nature of the Japanese markets caused this huge trade deficit. This closed nature of Japanese markets was characterized by complex Japanese trade customs and exclusive, overly elaborate distribution structure. The US asked Japan to modify these five 
non-tariff barriers to US business sectors: the patterns of financial saving and investments, taxation of real-estate, commerce and distribution systems, the exclusive trade customs by reinforcement of Fair-Trade Commission, tight business relationships, and price differences between US and Japan. These processes and pressures can be regarded as attempts to bring borderless globalization to Japan.

In contrast to the foregoing, the argument from the other extreme criticized the unconditional shift to a borderless globalization (Itami 1991). This argument insisted that globalization has two aspects: global distribution of the capital (e.g., money, goods and services, and information) and movement of human beings and transferring their habits. The logic of the economy is characterized by movement of the capital. Due to the development of information and communication technology, movement of the capital cannot be interrupted by any other means, except for political reasons. Human beings and their habits, however, cannot move and transfer at the same pace as capital can.

People in Japan who were afraid of the advancing-invading 'borderless globalization' toward Japan were relieved to hear the alternative of borderful-globalization because they would not have to change their customs and habits. As a consequence, the Japanese positively accepted US goods and services, but retained their cultural habits. Consider the shopping at the huge US retail chain Walmart as an example. Walmart entered the Japanese market in 2005, by establishing a subsidiary. When the Japanese consumers bought huge packages of food products - such as frozen French fries, spinach, and broccoli at Walmart - they shared them with neighbors. In other words, the American habits of buying and storing huge pack-sizes did not transfer over to Japan.

These are illustrations of the typical structure of the "Japanised" (and globalized) controversies. Major structural shifts begin a debate between two extreme positions, then each of these are unlearned soon. In turn, facts and experiences sublimate and blend the two positions into one. For instance, in relation to the Japanese management success mania of the 1970s, the blended position is that Japanese management sometimes works, but it sometimes fails when the conditions have changed. In that case, the important thing is to adjust as often as we can, even without logical consistency. Some Japanese may call it "aufheben" (to completely cancel, reorient, remove), but it should rather perhaps be characterized as ephemeralism - or, in colloquial terms - the 'Japanese Glocal'.

\section{What Others Can Learn from Japanese Glocal Processes}

Concerning the COVID-19 pandemic, the Japanese show attitude similar to what they had in response to the globalization situation. At first, we were not afraid of COVID-19. The first case was found on 
January 16, 2020. Around this time, most of Japanese regarded it as same as flu. Japanese Prime Minister Abe celebrated the Chinese New Year on January 25 and welcomed the Chinese to Japan. We did nothing against COVID-19 until February 25, 2020. At that time, Prime Minister Abe decided the lockdown of schools (elementary and junior high). Even then, the mass media and most people in Japan stressed that there was no need to close schools.

The situation, however, drastically changed on March 25, 2020. The cases in Japan increased precipitately and there was postponement announcement of the Olympic Games in Tokyo. As the World Health Organization (WHO) had already declared COVID-19 as a worldwide pandemic on March 11, 2020, Japanese news media and the public angrily condemned the delayed (March 25) government response. Specifically, TV programs and newspapers continued to loudly criticize the countermeasures by the government in April, 2020, despite the low level of cases and a small number of deaths, compared to US and EUs (although, the worst in the East Asia). Those criticisms included themes like "too late lockdown on April 7," "increase more and more PCR testing as soon as possible," and "legalize and enforce the lockdown in ways similar to other countries". The media seemed convinced and acted as if the government was responsible for everything in this pandemic crisis. Those who took this position cited Taiwan, Hong Kong, Korea, and New Zealand's success against COVID-19 as examples. Lockdown was seen as the key factor for success.

On May 8, 2020, Prime Minister Abe decided to continue the state of emergency to the end of May. This was the result of some politicians pandering to above critics. Another "flip-flop" critique began at this time. News media and members of the public began to criticize the extension of the emergency state declaration. Additionally, they argued that "the closures of stores and restaurants without compensation were wrong," "no necessity to deliver masks at the high cost of 436 million USD (USD1.00=JPY110)".

Additional "flip-flop" critique, again, began from mid-April, 2020, after the first wave peaked out. On June 7 , the government announced that it would provide huge economic support to the travel industry (transportation, accommodation, and hotel and lodging) because such sectors had been damaged strongly during "quasi-lockdown". It should be noted that the constitution of Japan prohibits the restriction of movement. Therefore, the lockdowns in Japan are always implemented as if they are based on people's own voluntarily decisions, rather than on government edicts. The travel-support program was called, "GO TRAVEL campaign" (and later GO EAT, enjoy EVENTS, and Neighborhood Shopping Centers were asked to join in). This program was budgeted at about 15.3 billion USD. This budget would be used 
primarily to offer price discounts to traveling consumers. Travelers could buy discounted transportation, lodging, and accommodation - up to a maximum of $35 \%$ - and later the government would compensate the sellers.

Most of negative opinions against the GO TRAVEL approach insisted the campaign should cease to operate, immediately. One of the biggest newspapers, Yomiuri Shinbunsha, surveyed public opinions on July 7,2020 . Their survey showed that $67 \%$ people replied that they would refrain from traveling, and only $15 \%$ of the people said they would plan small trips (e.g., in their own town and city, not across long distances or international borders).

Despite negative opinions, GO TRAVEL began on July 22, 2020. Many surveys about this campaign have been done. Results often showed negative attitude against any form of GO TRAVEL, even though new pandemic cases decreasing drastically before the campaign. Once the campaign began, the cases rapidly increased and, by August 7, 2020, reached 1605 per day. This number was the peak in the second wave. In a later assessment, the Japan Tourism Agency estimated that a total 52.6 million people used this campaign and the total amount of subsidy of 3.1 billion USD was given out till the end of November 2020. The campaign seemed to have achieved enough success, in spite of many negative opinions.

Though new cases had been decreasing from early August to middle of October, they started increasing again in October, 2020. Since October 25, the cases increased rapidly and, by November 14, reached 1736 per day. Some regional governors concluded that this was the result of the GO TRAVEL campaign. The campaign was suspended on December 28, 2020.

What the foregoing discussion shows is that the "flip-flop" process about public opinions in Japan regarding COVID-19 countermeasures continued throughout 2020: the Chinese New Year, reactions to WHO pandemic declaration, Olympics postponement, the voluntary vs. strict lockdown debates, the pro/con of the GO TRAVEL incentive campaign, and so on.

Interestingly, both sides of discussion always disappeared soon. For example, against the second wave of COVID-19 pandemic, some politicians - for instance, the governor of Tokyo, Koike - kept asking the public to avoid infecting others, still attempting to keep prohibitions on going out. In general, most of the governors in Japan started mitigating the restrictions of the declared emergency by June, 2020. Therefore, the famous extreme-crowded-commuters in trains were back and restaurants and shops reopened. Then, the Japanese realized that they seemed to be coping with the COVID-19 pandemic well. And, they believed they would 'unlearn' the restrictive COVID-19 pandemic behaviors soon. 
What can we learn from such flip-flop adaptation processes, that often - to external observers - appear to be funny-appearing processes, and the Japanese attitudes to major uncertainty producing events, like COVID-19? Perhaps, the lesson is the quick unlearning and always occurring adjustments. It can be characterized as momentary and ephemeral sequences of attitudes.

Such adaptation processes have been commented on as being parts of the Japanese traditional culture. The book The Chrysanthemum and the Sword by Ruth Benedict (1946) - heavily criticized for being a purely desk-research-based book, but also praised nonetheless for some insights - noted that the Japanese are "both aggressive and unaggressive, both militaristic and aesthetic, both insolent and polite, rigid and adaptable, submissive and resentful of being pushed around, loyal and treacherous, brave and timid, conservative and hospitable to new ways..." (p. 2).

Kent (1999), a western scholar teaching in Japan (and hence well-versed in Japanese language and culture), in her review of the Ruth Benedict book, made two key observations. Kent noted that the book, despite its 'armchair research' limitation, became a way for the Japanese to discover their own identity. The book, firstly, was regarded as a report by a researcher from the nation victorious in World War II, pointing out the peculiarities of (at that time, regarded as 'under-modernized') Japan. As the book gained in popularity, much more in Japan than in the West, another understanding became more accepted. It became clear that such research (e.g., the Benedict book) relativized each country's culture, and pointed out that Japan's was not 'under-modernized'. Indeed, despite the view of being under-modern, the Japanese found themselves doing very well, in economic and cultural terms.

Generally, when some external critiques and arguments appear, the Japanese are initially afraid of these, but then - as a result of such critiques - often become more intensely aware of (and often more accepting of) what they are doing. Based on this understanding, the flip-flop process can be seen as also a manageable approach to adapt to COVID-19 pandemic crisis.

During the COVID-19 emergency, newspapers, TV channels, and Social Networking Sites (SNS) said that the best thing we could do now was to stay home. The Japanese often said, "I do what I can do now." This attitude stems from the logic-confusion that does not distinguish between what we can do and what we should do. Logically, to do "what we should do" comes from a plan, especially from a detailed plan. In contrast, to do "what we can do, now" comes from a contingent response to events. The former demands analysis and forecasts about the future, the latter asks adaptation by the available skills and adjustments to ongoing events. 
Apparently, Japanese are good at the latter adjustments. During this pandemic, Japanese have dealt with many trials, such as washing hands for 30 seconds, wearing masks, gargling, staying home, avoiding dense, intimate, and close-contact settings, working at home (remote work or tele-work), and BCG (Bacillus Calmette-Guérin vaccine, the anti-tuberculosis vaccine, given to babies). Because of these multiple factors at play, we do not know the true reasons why Japan has coped with COVID-19 reasonably effectively. In addition, when some of these measures work, we unlearn what we have done; then, we move on the next stage. This speed of change is an indigenous characteristic of the Japanese. If there is something other countries can learn from Japan, it is to create a new mode of everyday life and adapt to it, rather than expecting to return to everyday life before COVID-19. Of course, the pandemic story is ongoing - as is the learning and the unlearning process from this pandemic. 


\section{References}

Abegglen, James C. (1958), The Japanese Factory: Aspects of Its Social Organization, Glencoe, IL: Free Press.

BBC (2020), "Coronavirus: Japan's Mysteriously Low Death Rate," BBC News, July 4, (accessed on September 1, 2020), [available at: https://www.bbc.com/news/world-asia-53188847]

Benedict, Ruth (1946), The Chrysanthemum and the Sword: Patterns of Japanese Culture, New York: Houghton Mifflin.

Harding, Robin (2020), "The 'Japan Model' that Tackled Coronavirus," Financial Times, June 3, 2020, (accessed on June 26, 2020), [available

at: https://www.ft.com/content/7a4ce8b5-20a3-40ab-abaf-1de213a6 640]

Itami, H. (1991), "Glocal" Management: Japanese Enterprises in Global Era. Tokyo, Japan: NHK Books [in Japanese].

Kent, Pauline (1999), "Japanese Perceptions of The Chrysanthemum and the Sword", Dialectical Anthropology, Volume 24, pp. 181-192.

Morita, Akio, Edwin M. Reingold and Mitsuko Shimomura (1986), Made in Japan: Akio Morita and Sony, New York: Harper Collins.

Saito, Tomoya (2020), "The Secret of Japan's Success in Combating COVID-19." Japan Times, June 2, 2020, (accessed on June 26, 2020), [available at: https://www.japantimes.co.jp/opinion/2020/06/02/commentary/ja pan-commentary/secret-japans-success-combating-covid-19/]

Shibuya, K. (2020), "The Countermeasures by the Prime Minister Abe stray far from Global Common Sense," Gendai On-Line, April 27, 2020, (accessed on June 26), [available at: https://gendai.ismedia.jp/articles/-/72010]

Shivendu, Shivendu, Suarav Chakraborty, Agnieszka Onuchowska, Ankit Patidar and Arpit Srivastava (2020), " Is There Evidence that BCG Vaccination has Non-Specific Protective Effects for COVID 19 Infections or Is It an Illusion Created by Lack of Testing?," MedRxiv, (accessed on April 24, 2020), [available at: https://www.medrxiv.org/content/10.1101/2020.04.18.20071142 v2.full]

Ohmae, Kenichi (1990), The Borderless World: Power and Strategy in the Interlinked Economy. New York, NY: Harper Business. 
The Economist (2021), "There have been $7 m-13 m$ Excess Deaths Worldwide during the Pandemic." The Economist, May 15, 2021 (accessed on June 13, 2021), available on-line, accessed on June 13, 2021), [available at:

https://www.economist.com/briefing/2021/05/15/there-have-bee n-7m-13m-excess-deaths-worldwide-during-the-pandemic/]

Vogel, Ezra F. (1979), Japan as Number One: Lessons for America. Boston, MA: Harvard University Press. 